United States

Department of Agriculture

Forest Service

Forest

Products

Laboratory

National Wood

in Transportation

Information

Center

Research

Paper

FPL-GTR-123

Us

.
In cooperation with the

United States

Department of

Transportation

Federal

Highway

Administration

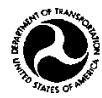

Guidelines for

Design, Installation,

and Maintenance of a

Waterproof Wearing

Surface for Timber

Bridge Decks

Richard E. Weyers

Joseph R. Loferski

J. Daniel Dolan

John E. Haramis

Joseph H. Howard

Lola Hislop

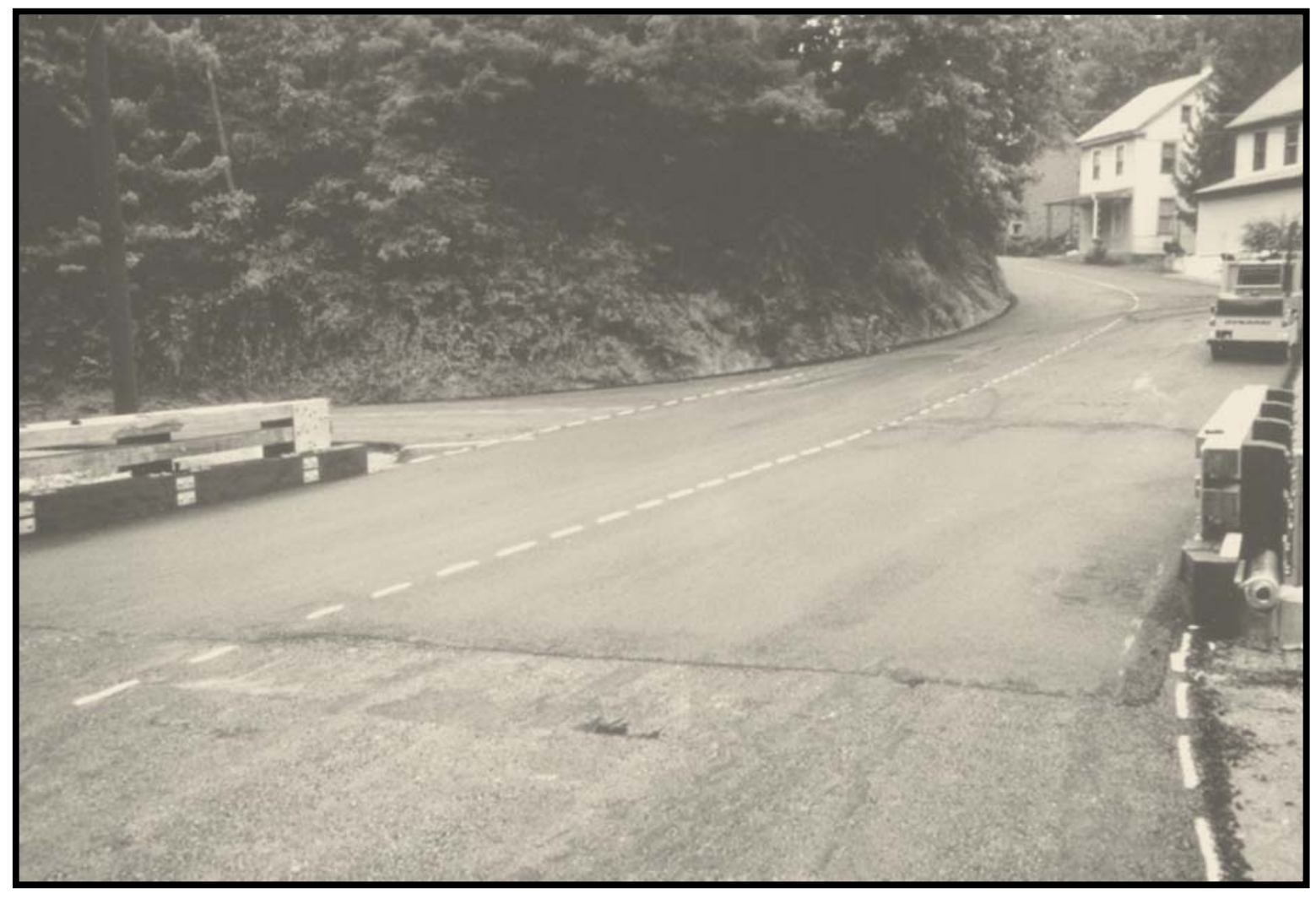




\section{Abstract}

To enhance long-term timber bridge performance, timber material must be protected from moisture. Wearing surfaces made of asphalt pavement with and without a waterproof membrane have been used to provide protection from moisture on timber decks. This type of wearing surface also protects the deck from other damage while providing a smooth, skid-resistant surface. However, the long-term performance of timber bridges has often not been satisfactory as a result of cracking of the wearing surface or separation of the asphalt or membrane from the deck. Cracking or separation allows moisture migration to the timber deck and decreases ride quality. To improve the performance of a wearing surface, it must be designed, installed, and maintained properly. This document provides guidelines for the proper design, installation, and maintenance of a waterproof wearing surface for timber bridge decks. The design section includes material descriptions and asphalt mixture recommendations. The installation section presents material testing, field inspection, detailed drawings, and errors to avoid. The maintenance section explains the typical signs of distress and corrective procedures.

Keywords: timber bridges, performance, wearing surface, asphalt, pavement, waterproof membrane

\section{January 2001}

Weyers, Richard E.; Loferski, Joseph R.; Dolan, J. Daniel; Haramis, John E.; Howard, Joseph H.; Hislop, Lola. 2001. Guidelines for design, installation, and maintenance of a waterproof wearing surface for timber bridge decks. Gen. Tech. Rep. FPL-GTR-123. Madison, WI: U.S. Department of Agriculture, Forest Service, Forest Products Laboratory. 15 p.

A limited number of free copies of this publication are available to the public from the Forest Products Laboratory, One Gifford Pinchot Drive, Madison, WI 53705-2398. Laboratory publications are sent to hundreds of libraries in the United States and elsewhere.

The Forest Products Laboratory is maintained in cooperation with the University of Wisconsin.

The use of trade or firm names is for information only and does not imply endorsement by the U.S. Department of Agriculture of any product or service.

The United States Department of Agriculture (USDA) prohibits discrimination in all its programs and activities on the basis of race, color, national origin, sex, religion, age, disability, political beliefs, sexual orientation, or marital or familial status. (Not all prohibited bases apply to all programs.) Persons with disabilities who require alternative means for communication of program information (Braille, large print, audiotape, etc.) should contact the USDA's TARGET Center at (202) 720-2600 (voice and TDD). To file a complaint of discrimination, write USDA, Director, Office of Civil Rights, Room 326-W, Whitten Building, 1400 Independence Avenue, SW, Washington, DC 20250-9410, or call (202) 720-5964 (voice and TDD). USDA is an equal opportunity provider and employer.

\section{Contents}

Introduction...1 Page




\title{
Guidelines for Design, Installation, and Maintenance of a Waterproof Wearing Surface for Timber Bridge Decks
}

\author{
Richard E. Weyers, Professor of Civil Engineering \\ Joseph R. Loferski, Associate Professor of Wood Science and Forest Products \\ J. Daniel Dolan, Associate Professor of Wood Science and Forest Products \\ John E. Haramis, Graduate Research Fellow, Civil Engineering \\ Joseph H. Howard, Research Associate, Civil Engineering \\ Virginia Polytechnic Institute and State University, Blacksburg, Virginia
}

Lola Hislop, General Research Engineer

Forest Products Laboratory, Madison, Wisconsin

\section{Introduction}

The use of timber as a bridge deck material has increased during the past several years. Protection of the timber from moisture is important to enhance long-term bridge performance. Moisture leads to biodeterioration, and changes in moisture content lead to dimensional instability in timber. Wearing surfaces made of asphalt pavement with and without a waterproof membrane have been used to provide protection from moisture on timber decks. This type of wearing surface also protects the deck from abrasion and other damage and provides a smooth, skid-resistant surface. However, the longterm performance of timber bridges has often not been satisfactory as a result of cracking of the wearing surface from localized deck deflections or separation of the asphalt or membrane from the deck. Typical cracking observed in the asphalt wearing surface of existing timber bridges is shown in Figure 1. Cracking or separation allows moisture migration to the timber deck and decreases ride quality.

Proper design, installation, and maintenance of a wearing surface will lead to longer service life. This document provides guidelines for the proper design, installation, and maintenance of a waterproof wearing surface for timber bridge decks. These guidelines are based on research to develop a waterproof asphalt wearing surface system that successfully protects transverse glued-laminated (glulam) panel decks while maintaining long-term pavement integrity (Howard 1997, Haramis 1997). These guidelines are applicable for all types of timber bridge decks. The wearing surface can be applied to timber that has been properly treated with various types of water- or oil-type preservatives, including chromated copper arsenate, creosote, and pentachlorophenol.
Satisfactory performance of the wearing surface is not dependent on the timber species.

Specifications for timber bridge wearing surfaces should be based on these guidelines. The guidelines herein provide basic information necessary for proper design, installation, and maintenance of an asphalt pavement with a waterproof membrane system. The design section includes material descriptions and asphalt mixture recommendations. The installation section presents material testing, field inspection, detailed drawings, and errors to avoid. The maintenance section explains typical signs of distress and gives corrective procedures.

\section{Background}

Asphalt wearing surfaces currently used on transverse glulam, nail-laminated, and panelized-nail- or spikelaminated timber bridge decks often deteriorate at or near joints. This is due to localized differential deflections causing high levels of localized strain and a subsequent loss of asphalt integrity. This results in cracks and potholes in the asphalt, causing a rough riding surface, swelling of the timber members, and the potential for long-term deterioration of the bridge as a result of decay. The purposes of a wearing surface are to provide a nonskid driving surface that is smooth to ride on and to protect the timber deck from traffic abrasion. An acceptable waterproof wearing surface would minimize geometric changes and biodeterioration of the wood caused by moisture penetration. For this reason, research was performed to determine an acceptable waterproof wearing surface system by combining asphalt and waterproof membranes. 
A three-layered system (asphalt base course, membrane, asphalt surface course) was configured to prevent cracking in the road surface. Strain energy created by the differential deflection between the deck elements was composed of both tensile and shear strains. The strain energy was dissipated at the interface of the deck and the base course, in the base course, and at the base course-membrane interface. Dissipation of the strain energy prevented cracking of the asphalt surface course at joints. This system, covered in these guidelines, had to meet performance criteria set forth at the initiation of the research (Howard 1997, Haramis 1997). The following were those performance criteria:

1. No visible unplanned cracks shall occur in the asphaltwearing surface throughout its service life.

2. The membrane is to remain waterproof. Liquid water transmission through the membrane shall not occur throughout the service life of the wearing surface.

3. The wearing surface is to provide a smooth riding surface throughout its service life; there are to be no potholes or other localized failure in the asphalt due to a lack of bond between the various wearing surface components.

4. For economic maintenance, service life of the timber bridge wearing surface must be at least equal to the service life of the asphalt roadway (for example, 15 to 20 years in rural areas with low average daily traffic).

This system met performance criteria in laboratory tests that consisted of localized differential deflection between joints and bond shear strength between each layer of the asphaltmembrane system. An added benefit of this system is that the same asphalt mixtures used to pave or repave the roadway can be used on the bridge. This is less costly than a specialized mix for short-span bridges. This system has been used on several bridges that have been in service for approximately 10 years with good performance. The system continues to be monitored to assess long-term performance.

Although the research was based on localized deflection, global deflection requirements need to be adhered to during design. Excessive live-load deflection (greater than L/360) and creep can and will cause strains in the asphalt wearing surface that may lead to cracking. At this time, a live-load deflection limit of L/500 is recommended for timber decks. If this global deflection limit is met, global deflection should be minimal and should not adversely affect the asphalt wearing surface.

\section{Design and Material Specifications}

The design of the timber bridge should conform to the recognized and adopted specifications for the jurisdiction where the bridge will be located. Timber bridges in the United States are usually designed in accordance with the requirements of the American Association of State Highway and Transportation Officials (AASHTO 1996). Other design resources are the National Design Specification for Wood Construction (NDS) (AFPA 1992), American Forest and Paper Association (AFPA 1996), and the American Institute of Timber Construction (AITC 1983). There is also a comprehensive manual by Ritter (1992) that describes the design of several types of timber bridges. The design process should be a rational, engineering-based procedure that includes the expected loads and properties for the materials used.

The waterproof wearing surface system described in this report performed acceptably in the laboratory based on a maximum differential deflection at panel joints of $1.27 \mathrm{~mm}$ (0.05 in.). The differential deflection value typically used in the design of deck panels is $2.54 \mathrm{~mm}$ (0.1 in.). It is assumed that the wearing surface system will perform acceptably at the greater deflection limit based on field performance.

However, keep in mind the difference between the typically used value and the research value for differential deflection during the panel design process.

For transverse panels on stringers, the differential deflection value is the live-load deflection determined during panel design and should take into consideration the effects of dowels or stiffeners, or both. For longitudinal panels with stiffeners, previous research has shown that differential deflection is limited to $2.54 \mathrm{~mm}$ ( $0.1 \mathrm{in}$.) for a global liveload deflection limit of L/360 (Ritter 1992). Stress- and naillaminated decks are not designed considering differential deflection but must meet global live-load deflection limits. Composite action between the bridge deck and the asphalt wearing surface should be neglected.

Deck material should be drilled, notched, or otherwise machined prior to pressure treating with preservative chemicals. The pressure treatment process and the preservative chemicals used should be in accordance with the standards of the American Wood-Preservers' Association (AWPA 1996) and the local jurisdiction. Specific items to include in pressure treatment specifications to reduce preservative bleed out are described by Ritter (1992). When deck panels must be fielddrilled, appropriate topical preservative chemical treatment should be applied to the affected area.

The recommended waterproof asphalt wearing surface system is a three-layered system that consists of (1) an asphalt base course placed directly on the wood deck, (2) a preformed waterproof sheet membrane placed on top of the base course, and (3) an asphalt surface course placed over the membrane. The following presents components and system performance specifications. 


\section{Asphalt Base and Surface Course}

Modern timber bridges are often constructed on rural or secondary roadways with low to moderate daily traffic. Asphalt base and surface course mixtures should be based on jurisdictional requirements. Superpave performance criteria may be used as an alternative (Asphalt Institute [n.d.]a). Superpave Design Level 1 performance is defined as adequate for cumulative total equivalent single axle load of less than $10^{6}$ (Asphalt Institute [n.d.]a). Binder grade is selected by geographic area, pavement temperature, or air temperature (Asphalt Institute [n.d.]b).

Materials should conform to Superpave Design Level 1, as modified by local agencies. Details on two surface course mixtures (SM) and two base course mixtures (BM) that have performed satisfactorily in laboratory tests and in a field application are given in the Appendix.

\section{Membrane}

The membrane should be a preformed, asphalt-impregnated, waterproof, self-adhering sheet compatible with the asphalt base and surface mixture. Table 1 describes performance properties for the membrane.

In addition, the system should be capable of exceeding 90,000 test cycles at a differential panel deflection of $1.27 \mathrm{~mm}(0.05 \mathrm{in}$.) without tearing or punching the membrane. The full-scale panel test used to determine this performance is described by Howard (1997). Three membrane products that were tested (Howard 1997) and conformed to these requirements were M400A waterproof membrane fabricated by Protecto Wrap Company (Denver, Colorado), Petrotac self-adhesive non-woven fabric manufactured by Phillips Fiber Corp. (Greenville, South Carolina), and Bituthene 5000 fabricated by W. R. Grace Co. (Cambridge, Massachusetts). Other membranes may be acceptable; check with manufacturers for performance properties. Membranes should be supplied with a mastic to seal the membrane edges, if necessary.

Table 1-Membrane performance properties

\begin{tabular}{lll}
\hline Parameter & \multicolumn{1}{c}{ Criteria } & Test reference \\
\hline Thickness & $\begin{array}{l}\text { No one measurement } \\
<1.52 \text { nor }>2.03 \mathrm{~mm} \\
(<0.06 \mathrm{nor}>0.08 \mathrm{in} .)\end{array}$ & $\begin{array}{l}\text { From } 32 \text { meas- } \\
\text { urements as } \\
\text { described in } \\
\text { Haramis } 1997\end{array}$ \\
Unit weight & $>1.37 \mathrm{~kg} / \mathrm{m}^{2}\left(>0.28{\left.\mathrm{lb} / \mathrm{ft}^{2}\right)}^{2}\right)$ & Haramis 1997 \\
& $>880.55 \mathrm{~kg} / \mathrm{m}^{3}\left(>55.0 \mathrm{lb}_{\mathrm{ft}}{ }^{3}\right)$ & \\
$\begin{array}{l}\text { Bond shear } \\
\text { strength }\end{array}$ & $\begin{array}{l}>172,350 \mathrm{~Pa}\left(>25 \mathrm{lb} / \mathrm{in}^{2}\right) \\
200 \text { freeze-thaw cycles }\end{array}$ & Haramis 1997 \\
$\begin{array}{l}\text { Electrical } \\
\text { resistance }\end{array}$ & $\begin{array}{l}>1.1 \mathrm{M} \Omega \text { after } 100 \text { freeze- } \\
\text { thaw cycles }\end{array}$ & Haramis 1997 \\
\hline
\end{tabular}

\section{Installation}

This section describes the requirements for applying the asphalt-membrane system to new and existing wood bridge decks. The configuration of the layered system is shown in Figure 2. All preparation and application procedures should meet or exceed the requirements described in this Installation section.

\section{Curbs and Scuppers}

This section addresses installation of the wearing surface system in the curb and scupper areas of the bridge deck. This portion is addressed first because the curbs and scuppers can be installed on the deck prior to installation of the wearing surface system on the remainder of the deck. All possible cases of curb and scupper installation are addressed, considering that the various components can be installed at different times.

\section{Installed Prior to Base Course}

Figure 3 presents the design detail for decks with curbs and scuppers installed before the base course is placed. Prior to placing the membrane, the deck should be clean of debris and excess preservative. A strip of membrane, running the length of the deck, is folded down the vertical face of the deck to $50 \mathrm{~mm}(2 \mathrm{in}$.) beneath the bottom of the deck (Fig. 4). Then, the strip of membrane is adhered to the deck surface at a distance equal to the width of the scuppers. A strip of membrane is cut along the length of the deck, leaving a section of membrane extending a minimum of $125 \mathrm{~mm}$ (5 in.) beyond the face of the scuppers. Do not adhere this section to the deck.

After placing the membrane strip and prior to placing the scuppers, the membrane should be perforated at all bolt hole locations. A mastic sealant should be applied along the perforated membrane edges to inhibit moisture penetration between the membrane and deck. The curb and scuppers are then installed, and the 125-mm (5-in.) membrane strip is held along the vertical face of the curbs and scuppers until after the base course is laid. After the base course is laid and cleaned of debris, the 125 -mm (5-in.) membrane strip is adhered to the base course. The main membrane should overlap the 125-mm (5-in.) membrane strip a minimum of $75 \mathrm{~mm}$ (3 in.). To inhibit moisture penetration, all membrane edges should be sealed with a mastic supplied by the manufacturer of the membrane.

\section{Curbs Only, Installed Prior to Base Course}

Figure 5 presents the curb without scuppers detail. The curb is installed, and the base course is laid and cleaned of debris. A curb membrane strip is adhered to the vertical face of the curb and folded onto the horizontal section of the base course. The membrane should extend a minimum of $50 \mathrm{~mm}$ (2 in.) up the curb vertical face and $100 \mathrm{~mm}$ (4 in.) on the 
base course. The main membrane should overlap the curb membrane strip a minimum of $75 \mathrm{~mm}$ (3 in.). To inhibit moisture penetration, all edges should be sealed with a mastic supplied by the manufacturer of the membrane.

\section{Installed on Existing Decks}

Existing bridge decks with curbs and scuppers should have the membrane applied using the details shown in Figure 6. The curbs and scuppers should be inspected for deterioration, and worn elements should be replaced. After the base course has been laid, the base course and deck between scuppers should be cleaned of debris. An edge membrane strip must be adhered to the vertical face of the deck edge. The bottom of the strip should extend $50 \mathrm{~mm}$ ( 2 in.) beneath the bottom of the deck (Fig. 4), and the top of the strip should extend a minimum of $50 \mathrm{~mm}$ ( 2 in.) on the vertical face of the scuppers. The membrane should be cut at openings between scuppers and adhere to the deck surface.

A scupper membrane strip should be adhered to the deck and the vertical faces of the scuppers between each scupper. The membrane should extend a minimum of $25 \mathrm{~mm}$ ( 1 in.) beyond the scuppers on both sides and a minimum of $50 \mathrm{~mm}$ ( 2 in.) up the vertical face of each scupper. At the outside scupper edges, the membrane should be cut and folded down the deck edge and to the sides on the scupper vertical faces, overlapping the edge membrane strip. At the roadside edges, the membrane should be cut and adhered to the base course and the sides on the scupper vertical faces.

A curb membrane strip must be adhered to the roadside vertical face of the scuppers and the base course. The membrane should extend a minimum of $50 \mathrm{~mm}$ ( 2 in.) up the vertical face of the scupper and a minimum of $100 \mathrm{~mm}$ (4 in.) on the base course. At openings between scuppers, the membrane should be cut and adhered between the scuppers, overlapping the scupper membrane strip.

The main membrane should overlap the curb membrane strip a minimum of $75 \mathrm{~mm}$ ( 3 in.). To inhibit moisture penetration, all edges need to be sealed with a mastic supplied by the manufacturer of the membrane. Alternatively, the curb and scuppers may be removed prior to placing the membrane and reattached after the membrane is placed. If this procedure is performed, the requirements in the sections titled "Installed Prior to Base Course" or "Installed After Base Course" should be followed.

\section{Installed After Base Course}

Figure 7 presents the design detail for decks with curbs and scuppers installed after the base course is laid. Blocks are used to delineate the scupper and curb locations. The base course is laid, and the blocks are then removed. The deck in the curb and scupper area is cleaned of debris and excess preservative (see "Deck Preparation"), and the base course is also cleaned of debris. The main membrane is installed in a continuous sheet over the entire deck. The membrane sheet, along the deck edge, should be folded down the vertical face of the deck edge to $50 \mathrm{~mm}$ ( 2 in.) beneath the bottom of the deck to form a drip edge (Fig. 4). After placing the membrane and prior to placing the scuppers, the membrane must be perforated at all bolt hole locations. A mastic sealant should be applied along the perforated membrane edges to inhibit moisture penetration between the membrane and deck.

\section{Deck-to-Roadway Transition}

For the deck-to-roadway transition, the same wearing surface system used on the bridge can continue onto the roadway (Fig. 8). The membrane should extend a minimum of $1 \mathrm{~m}$ ( $3 \mathrm{ft}$ ) beyond the edge of the back face of the abutment wall to prevent surface water from draining through the asphalt at the abutment front face wall and wetting the wood components of the bridge. An option is to place the membrane down the back vertical face of the backwall or vertical face of the deck end, depending on the type of bridge, whether or not it is an asphalt-surfaced roadway, and what the design plan is for the bridge deck to roadway joint. It may be easier to end the system at the joint, protect the end of the deck with the membrane, and fill the joint instead of paving over a soft joint (Fig. 9). The wearing surface system is not designed to bridge gaps without cracking and possibly tearing the membrane.

\section{Deck Preparation}

To prepare a new deck for installing a wearing surface, the surface of the bridge deck should be swept to remove loose dirt, gravel, or other debris before applying the base course (Fig. 10). Excess preservative chemicals may interfere with the bond between the base course and the deck. Blotters such as sand or absorbent cloth remove excess chemicals that may be present on the surface of the deck (Fig. 11). The blotter material should be removed just prior to placing the base course.

To prepare an existing deck, the asphalt surface should be removed and the deck inspected to ensure deterioration has not occurred. Deteriorated wood components should be repaired or replaced. Then, the bridge deck must be swept to remove loose dirt, gravel, or other debris (Fig. 10).

\section{Asphalt Base Course}

The asphalt base course should be placed and compacted in accordance with state Department of Transportation specifications or other governing agency specifications (Figs. 12 and 13). Figure 2 shows the waterproof wearing surface system that incorporates cross slope for drainage. The base course establishes a cross slope equal to $20.8 \mathrm{~mm} / \mathrm{m}$ $(0.25 \mathrm{in} / \mathrm{ft})$. The minimum thickness of the base course, $t_{1}$, at the curb is twice the thickness of the base course maximum aggregate size. For a maximum aggregate size of $19 \mathrm{~mm}$ (0.75 in.), $t_{1}$ would be $38 \mathrm{~mm}$ (1.5 in.) at the curb and would 
increase to $114 \mathrm{~mm}$ (4.5 in.) at the roadway centerline for a two-lane bridge with 3.66-m- (12-ft-) wide lanes. To reduce the dead load, the maximum aggregate size may be reduced. For a 9 -mm (0.375-in.) maximum aggregate size, $t_{1}$ would be $19 \mathrm{~mm}(0.75 \mathrm{in}$.) and would increase to $95 \mathrm{~mm}$ (3.75 in.) at the centerline. Cross slope is not necessary on bridges with sufficient camber or slope across the length of the bridge. In these cases, $t_{1}$ would be the minimum thickness across the entire width of the bridge.

Experience has shown that oil-type preservatives can bleed from timber bridge decks during paving of the base course, even from wood that has been steam cleaned prior to deck construction and blotted prior to paving. When the hot asphalt contacts the wood surface, the viscosity of the preservative decreases and the preservative flows to the surface (Fig. 14). However, this bleeding of chemical is usually minor and has not adversely affected performance of the wearing surface in field applications.

\section{Main Membrane}

Immediately prior to placing the membrane, the base course must be cleaned to remove all loose dirt and debris. The asphalt base course surface should be sufficiently clean, cool, and dry for the membrane to adhere to the asphalt (Fig. 15). The membrane should be placed in shingle fashion, working from the lower elevation to the higher elevation of the deck. This allows water to drain to the low areas of the deck and prevents water from accumulating at the seams. This may be from curb to centerline for decks with cross slope, from lower end to elevated end for decks with a longitudinal slope, or deck ends to midspan for decks with camber. The edges (parallel to slope) of the membrane should be overlapped a minimum of $75 \mathrm{~mm}$ ( 3 in.), and the ends (perpendicular to slope) overlapped a minimum of $150 \mathrm{~mm}$ (6 in.). End joints should be staggered to a minimum of $305 \mathrm{~mm}$ (12 in.)

(Figs. 16-21).

The membrane should be rolled into place using a linoleumtype roller, taking special care to eliminate air pockets. Air pockets greater than $75 \mathrm{~mm}$ (3 in.) in any dimension remaining after completion of installation should be punctured with a sharp pointed object (an ice pick, for example) and the air forced out. The area surrounding the puncture should be coated with mastic and a membrane patch applied with a 75-mm (3-in.) minimum overlap. All edges and ends of the membrane must be sealed with a mastic supplied by the manufacturer.

Test the membrane in three locations to ensure it has adhered to the base course properly. To test the shear strength, a 305- by 305-mm (12- by 12-in.) section of the membrane should be cut out and lifted from the base course with a scale attached to the edge. The minimum force required to lift the test section should be $222 \mathrm{~N}(50 \mathrm{lb})$.

\section{Asphalt Surface Course}

Within 2 days of the application of the membrane, the asphalt surface course must be placed. All construction traffic must stay off the membrane-covered deck prior to application of the asphalt surface course. To ensure that the shear bond strength between the membrane and surface course exceeds $172 \mathrm{kPa}\left(25 \mathrm{lb} / \mathrm{in}^{2}\right)$, the membrane should be clean of all dirt and debris. The asphalt surface course should be laid and compacted in accordance with governing agency specifications (Figs. 22 and 23). For all bridges, the surface course thickness, $t_{2}$, remains the same across the width of the bridge and is typically 25 to $29 \mathrm{~mm}$ (1.0 to 1.125 in.) (Fig. 2).

\section{Maintenance}

To ensure the integrity of the asphalt wearing surface and its protective qualities, routine maintenance needs to be performed. As with asphalt-surfaced roads, distress will occur with time as a result of vehicle loadings and environmental effects. Routine maintenance can detect and correct distress in a cost-effective manner and ensure the comfort and safety of users. As on roads, distress of the asphalt wearing surface on bridges may be a sign of underlying problems. Those who perform maintenance as well as those who perform bridge inspections should determine the cause of asphalt distress and use this information to determine the necessary maintenance, including that of the bridge structure.

This section discusses the various types of asphalt wearing surface distress that can occur on timber bridges (Ritter 1992, Asphalt Institute 1989, Shook and Shannon 1987). Each discussion includes a description of the distress, a statement of whether or not inspection of the structural integrity of the bridge is warranted, the reasons for performing maintenance, and a description of maintenance alternatives, along with the material and work specifications for maintenance of the bridge's wearing surface.

A table in The Asphalt Handbook (Asphalt Institute 1989) lists various alternatives for dealing with different forms of asphalt wearing surface distress and includes the possible causes of distress on roads as well as alternatives for minimizing excessive distress. The importance of determining the cause of the distress and performing the proper maintenance based on that cause cannot be overemphasized.

\section{Cracks}

Cracks typically occur at three locations: (1) along the ends of the bridge at the abutment, (2) along the joints of glulam and panelized nail- or spike-laminated deck panels, and (3) between the laminations of nail- or stress-laminated decks. However, cracks along joints should be minimal if the interpanel deflection criterion (see "Design and Material Specifications") is followed. Abutment movement should be investigated as a cause of end cracks. Excess impact caused 
by a rough approach onto the deck should be investigated as a cause of cracks between panels or laminations. If cracks appear between laminations, delamination of nail- or spikelaminated decks or reduction in bar force in stress-laminated decks should both be investigated as possible causes. Maintenance is important to limit effects of incompressible material filling the crack and to prevent moisture from migrating between the surface course and membrane layers or to the timber components. Maintenance should include a thorough cleaning of incompressible material from the crack, drying of the crack, and filling. For 6- to 19-mm- (0.25- to 0.75-in.-) wide cracks, a hot-applied asphalt crack sealer should be used to fill the crack. For cracks greater than 19-mm(0.75-in.-) wide, a slurry or sand asphalt should be used to fill the crack. It is impractical to individually fill less than 6-mm- (0.25-in.-) wide cracks. However, these cracks should be noted for future bridge inspections and maintenance.

\section{Slippage Cracks and Potholes}

Slippage cracks affect the entire thickness of the wearing surface, whereas potholes are typically limited to the surface course. Slippage cracks are probably due to excessive preservative treatment still present prior to placement of the base course or continued leaching of the preservative after placement. Potholes can occur if moisture migrates between the surface course and the membrane. Potholes can also occur in the aggregate-surfaced bridge approaches along the ends of the bridge. It is important to perform maintenance on these distress areas for driver safety, to prevent additional moisture migration, and to prevent excessive dynamic loads due to a rough bridge approach.

The only method for correcting slippage cracks is patching. For slippage cracks, the full wearing surface depth needs to be replaced. From the slippage crack, the entire thickness of the wearing surface material must be removed along the length and width of the deck until a sufficiently adhered base course is reached. Then, the surface course should be removed another $75 \mathrm{~mm}$ ( 3 in.) around the entire perimeter to ensure sufficient overlap of the new section of membrane. The removed sections should form a square or rectangular shape with vertical edges. Upon completion, check the patched area with a straight edge to ensure proper drainage.

For potholes, remove the surface course until a sufficiently adhered surface course is reached. The removed section should form a square or rectangle with vertical edges. Any areas of membrane that have been damaged during removal of the surface course should be patched. A tack coat must be applied to the vertical edges, and the area must be filled and compacted in accordance with the guidelines under the heading "Asphalt Surface Course." Potholes in unpaved bridge approaches should also be filled and compacted. An asphalt wearing surface extending a minimum of $23 \mathrm{~m}(75 \mathrm{ft})$ beyond the ends of the bridge should be laid.

\section{Wearing Surface Distortions}

Distortions include channeling (rutting), corrugations, shoving, depressions, and upheaval. These distresses can be caused by an unstable mix design, slippage of the wearing surface, slippage of laminations in nail-, spike-, or stresslaminated decks, or expansion of panels in glulam decks. Inspection of the underside of the bridge must be performed, especially on nail-, spike-, or stress-laminated decks (especially the $\mathrm{T}$ and Box systems) where lamination slip might be the cause of longitudinal cracks and channeling. For driver safety and continued drainage of water from the bridge surface, it is important to perform maintenance on these types of distress.

There are two methods to correct these distresses. These methods may be used separately or in conjunction with each other. One method is cold milling or hot planing, which is used to reduce high points. This method must be used with caution to prevent damaging the membrane, which is located at a relatively shallow depth. The second method is to apply a leveling course that raises low areas by placing and compacting an asphalt mix to the elevation of the surrounding wearing surface. It is wise to determine, on a case-by-case basis, the cause of the distortion to determine the proper maintenance procedure. If distortions are due to an unstable mix or wearing surface slippage, patching may be necessary. If distortions are due to deck performance, maintenance of the bridge structure may be required.

\section{Slippery Surfaces}

Slippery surfaces can occur as a result of asphalt bleeding in an unstable mix or as a result of polished aggregate due to traffic wear. Both are hazardous to drivers due to reduced traction. Asphalt bleeding can be corrected by adding and compacting hot aggregate (such as chip seal) to absorb the excess asphalt, by cold milling, or by placing an overlay. Polished aggregate can only be corrected with an overlay. Acceptable overlays include a thin, hot-mix friction course, a sand seal, or an aggregate seal. For all overlays, the chosen aggregate should be hard, angular, and nonpolishing.

\section{Surface Debris}

Although debris is not a type of distress of the asphalt wearing surface, it does require attention. Debris can accumulate on the surface, typically along the curbs, especially if the bridge is located on an unpaved road. Debris is tracked onto the bridge and causes wear of the surface as well as blockage of water drainage. Asphalt approaches will minimize the accumulation of debris, and any accumulation should be cleared periodically to allow for proper water drainage. Blockage of water drainage can also occur with the accumulation of snow and ice along the curb during snow plowing operations. Blockage of this type should be cleared. 


\section{References}

AASHTO. 1996. Standard specifications for highway bridges. 16th ed. Washington, DC: American Association of State Highway and Transportation Officials. 394 p.

AFPA. 1992. National design specification for wood construction. Washington, DC: American Forest and Paper Association.

AFPA. 1996. Load and resistance factor design manual for engineered wood construction. Washington, DC: American Forest and Paper Association.

AITC. 1983. American national standard for wood products-Structural glued laminated timber. ANSI/AITC A190.1. Englewood, CO: American Institute of Timber Construction. $16 \mathrm{p}$.

Asphalt Institute. [n.d.]a. Superpave level 1 mix design. Superpave Series 2 (SP-2). Lexington, KY: Asphalt Institute. $117 \mathrm{p}$.

Asphalt Institute. [n.d.]b. Performance graded asphalt binder specification and testing. Superpave Series 1 (SP-1). Lexington, KY: Asphalt Institute. 69 p.

Asphalt Institute. 1989. The asphalt handbook. Manual Series 4 (MS-4). Lexington, KY: Asphalt Institute.

AWPA. 1996. Standards. Woodstock, MD: American Wood-Preservers' Association. 374 p.

Haramis, J.E.1997. Investigation of bond strength and water tightness of waterproof asphalt concrete wearing surfaces for timber bridge decks. Blacksburg, VA: Virginia Polytechnic Institute and State University. Master of Science thesis in civil engineering.
Howard, J.N. 1997. Investigation of the structural behavior of asphalt/wood deck systems for girder bridges. Blacksburg, VA: Virginia Polytechnic Institute and State University. Master of Science thesis in civil engineering.

Ritter, M.A. 1992. Timber bridges-design, construction, inspection, and maintenance. EM 7700-8. Washington, DC: U.S. Department of Agriculture, Forest Service, Engineering Staff.

Shook, J.F.; Shannon, M.C. 1987. Synthesis of technology on bituminous surfacing materials for low-volume roads. Report FHWA/DF-87/001. Washington, DC: U.S. Department of Transportation, Federal Highway Administration.

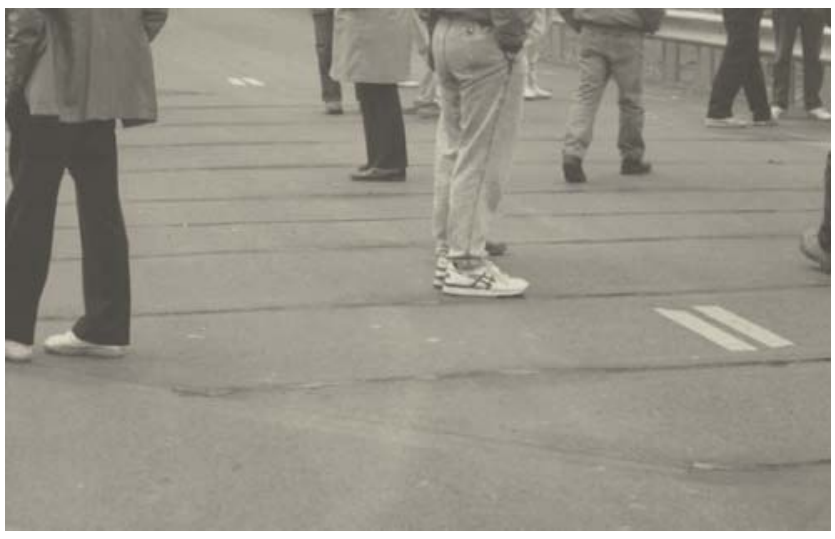

Figure 1-Asphalt cracking on beam with transverse glulam panel timber bridge.

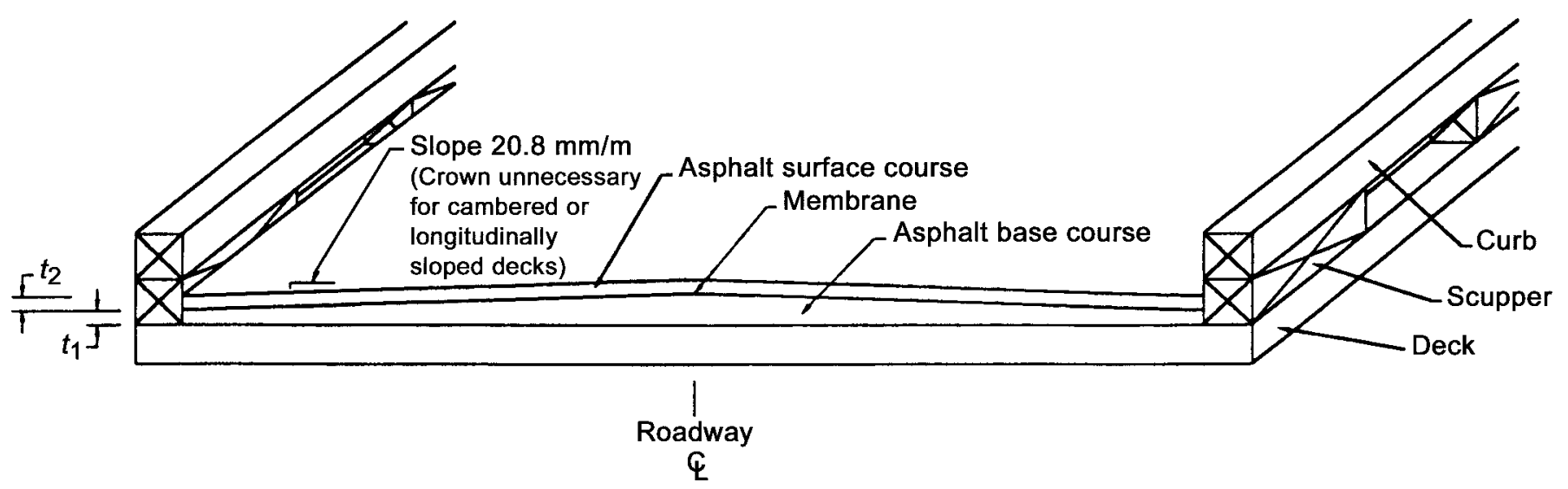

Figure 2-Configuration of three-layer asphalt wearing surface system: $t_{1}$ is minimum thickness of the base course; $t_{2}$ is surface course thickness (drawing not to scale). 

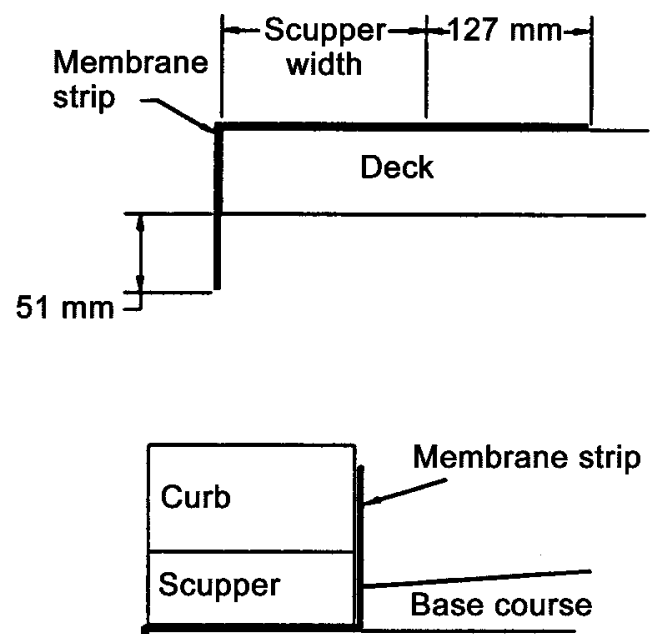

Deck
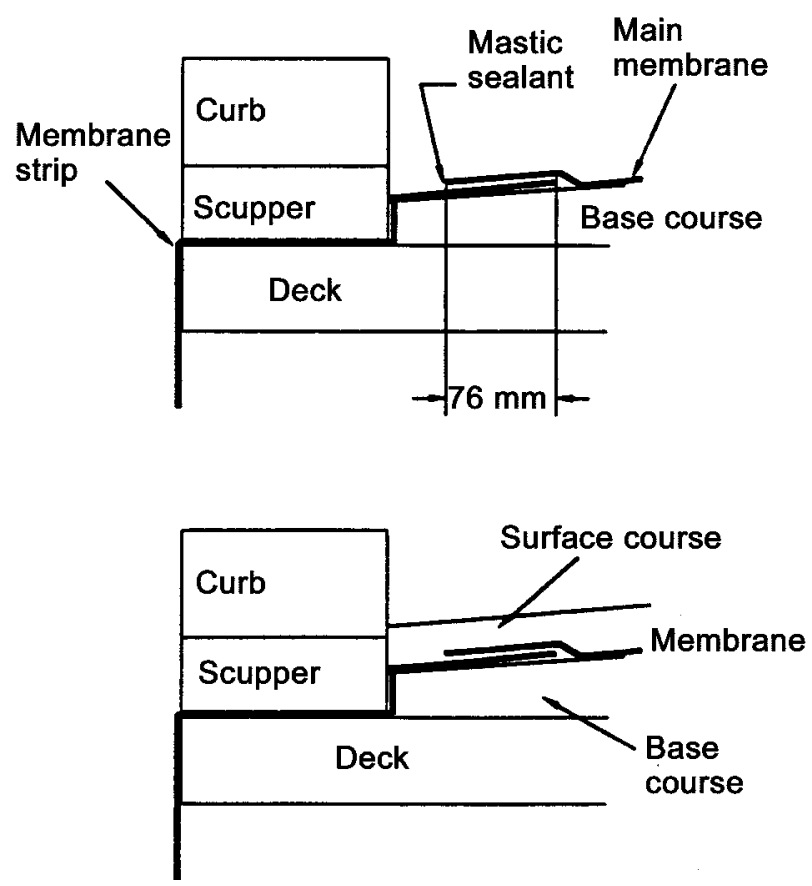

Adhere membrane strip to deck edge and to deck for width of scupper.

Do not adhere 127-mm width of membrane strip.

Drill and seal holes for scupper and curb bolts.

Install scupper and curb.

Temporarily hold $127-\mathrm{mm}$ width of membrane strip against vertical face of scupper and curb.

Place base course.

Adhere membrane strip to base course.

Overlap membrane strip with main membrane.

Seal membrane edge with mastic.

Place remainder of main membrane on base course in shingle fashion.

Place surface course.

Figure 3-Membrane installation when scuppers and curbs are installed prior to base course. 


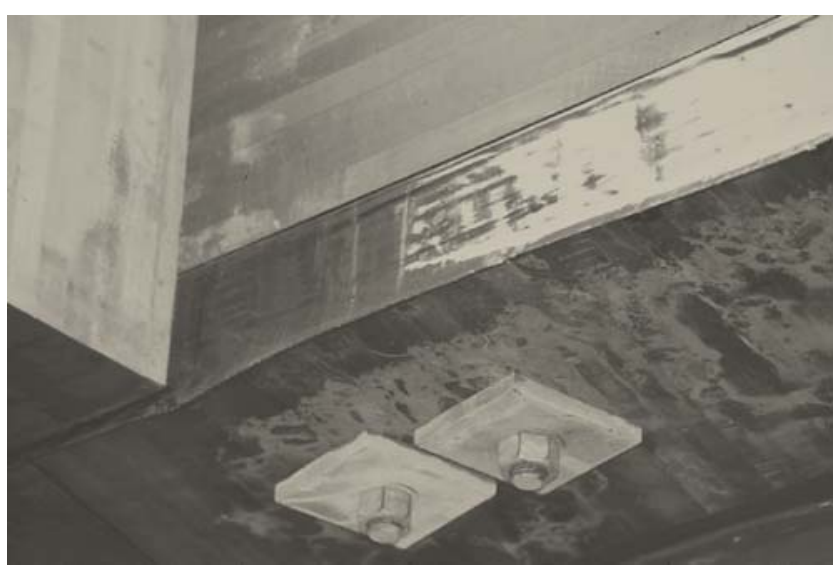

Figure 4-Membrane drip edge along deck edge.

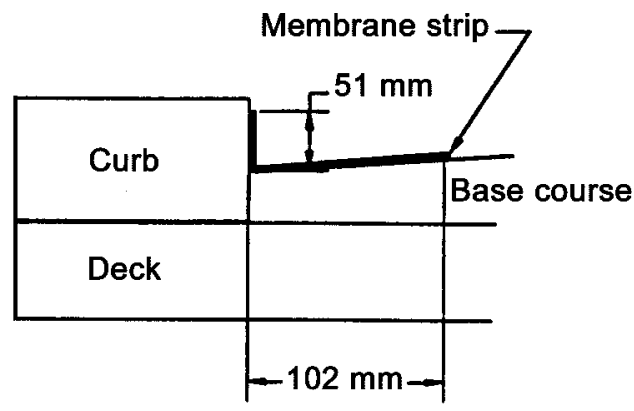

Install curb.

Place base course.

Adhere membrane strip against vertical face of curb and on base course.

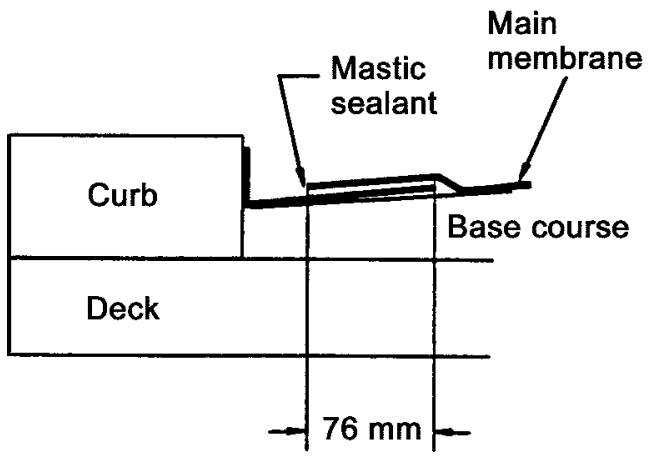

Overlap membrane strip with main membrane. Seal membrane edge with mastic.

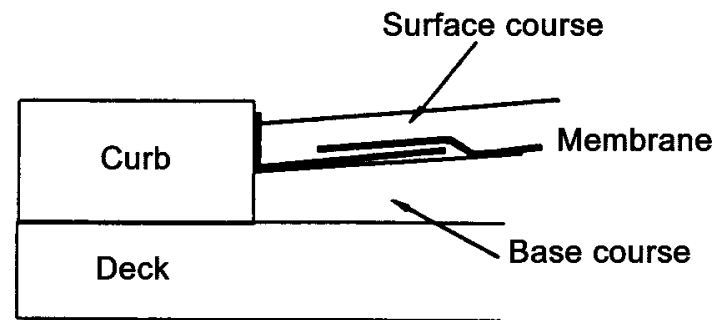

Place remainder of main membrane on base course in shingle fashion.

Place surface course.

Figure 5-Membrane installation when no scuppers are installed. 

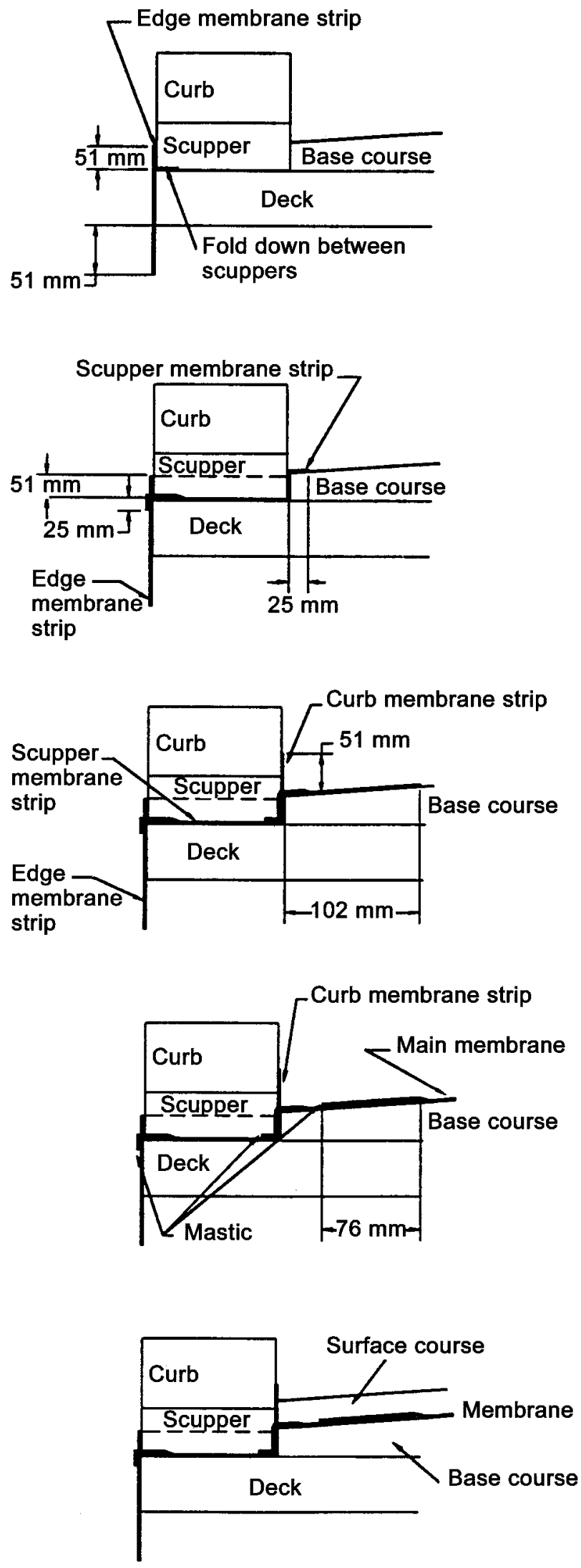

Place remainder of main membrane on base course in shingle fashion.

Place surface course.

Figure 6-Membrane installation when scuppers and curbs are installed on existing deck. 

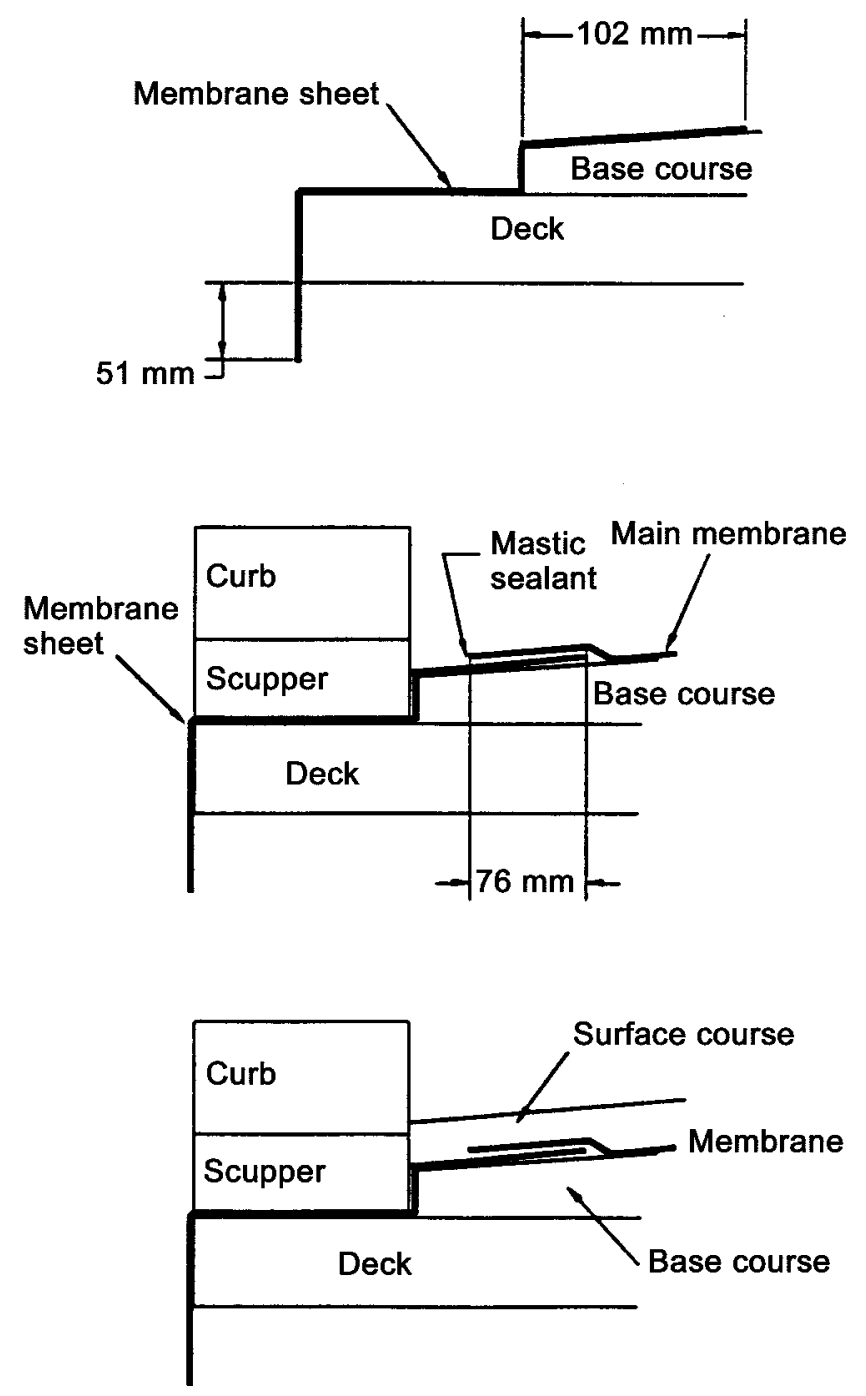

Place base course using blocks to delineate scupper position.

Adhere membrane sheet to deck vertical edge, deck surface, and base course.

Drill and seal holes for scupper and curb bolts.

Install scupper and curb.

Overlap membrane sheet with main membrane.

Seal membrane edge with mastic.

\section{Place remainder of main membrane on base} course in shingle fashion.

Place surface course.

Figure 7-Membrane installation when scuppers and curbs are installed after base course.

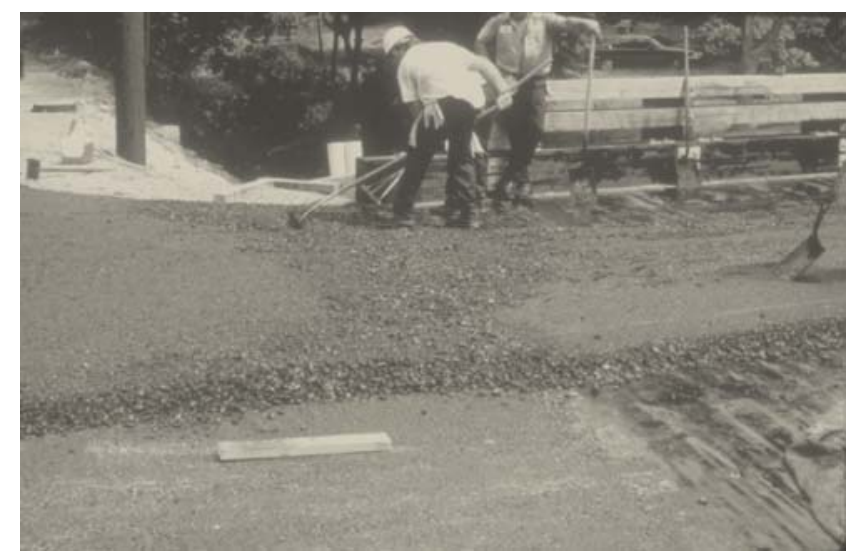

Figure 8-Deck to roadway transition. 


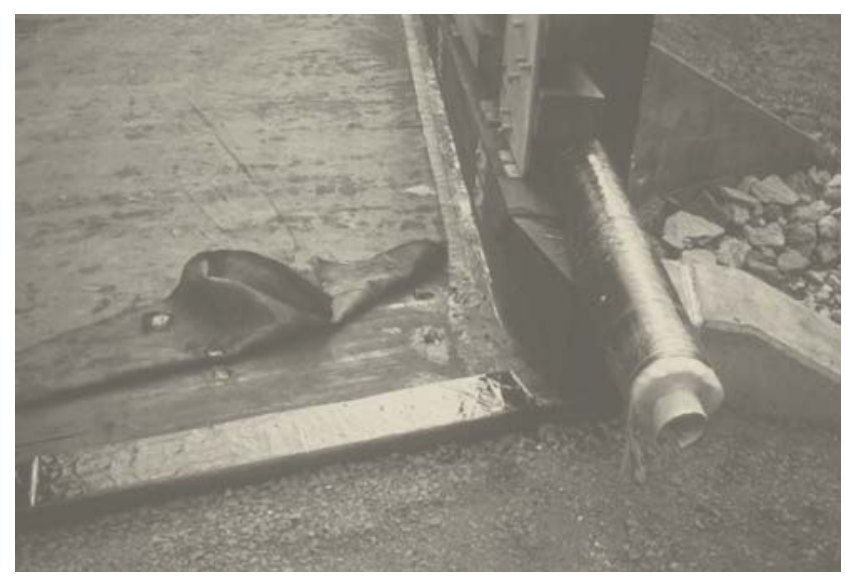

Figure 9—Membrane folded over deck end.

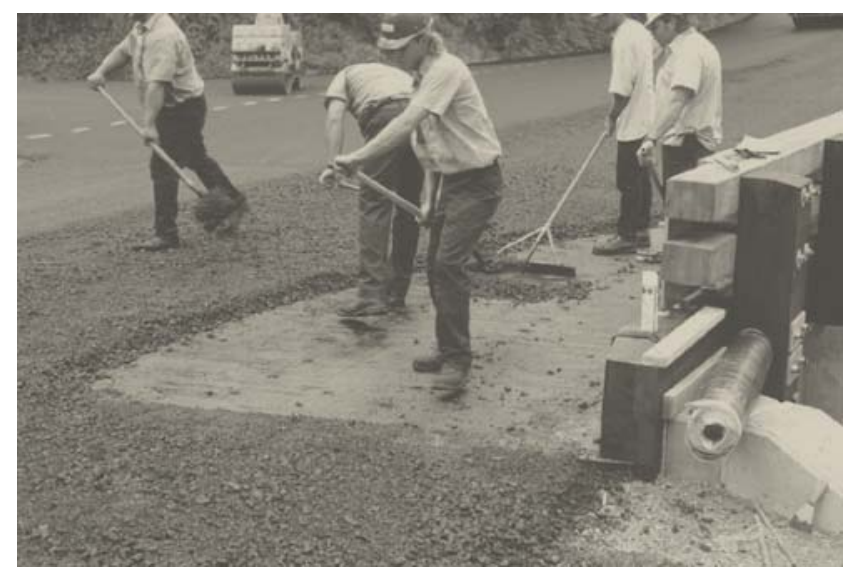

Figure 10-Debris cleaned off deck prior to laying base course.

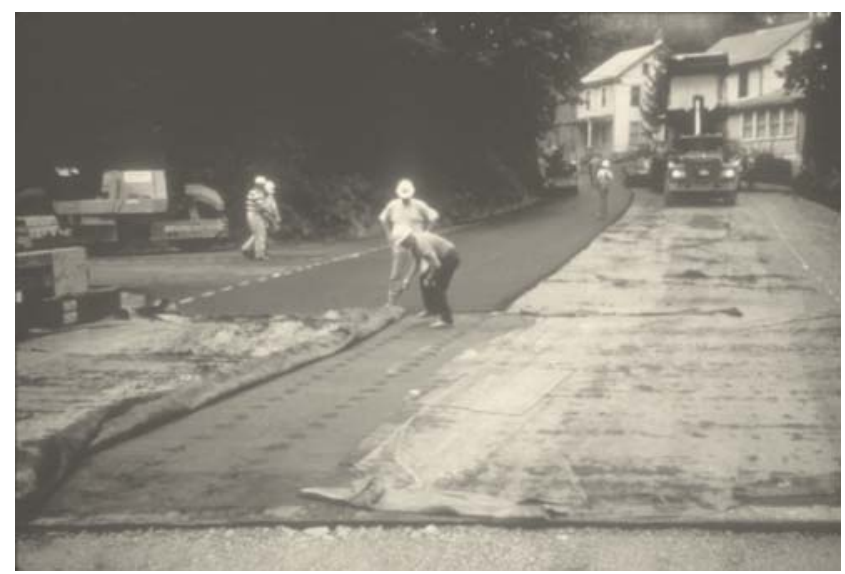

Figure 11-Absorbent cloth used to remove excess preservative.

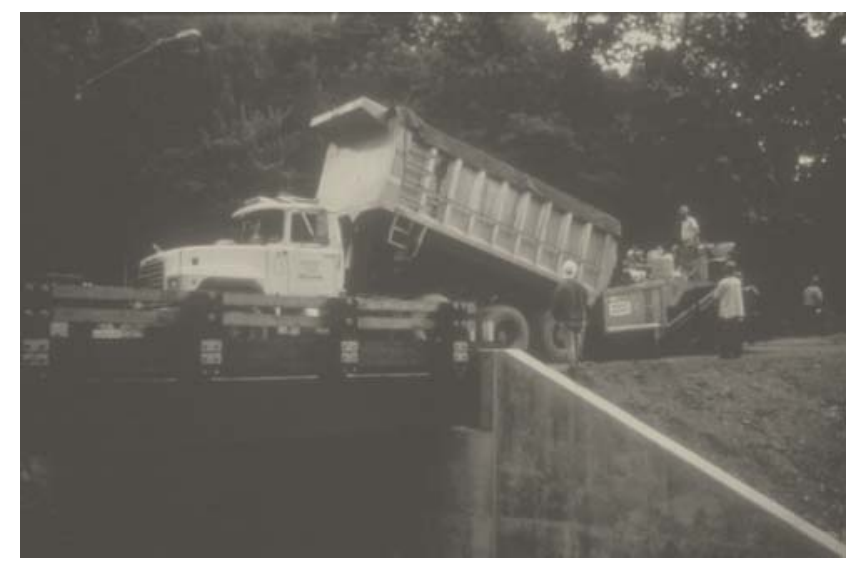

Figure 12-Dump truck filling paving equipment with asphalt.

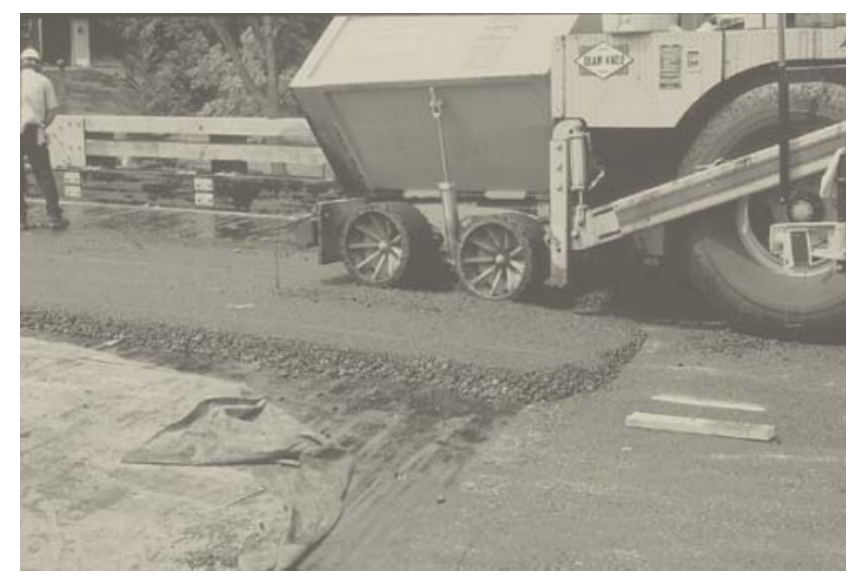

Figure 13-Asphalt being laid and compacted according to agency regulations.

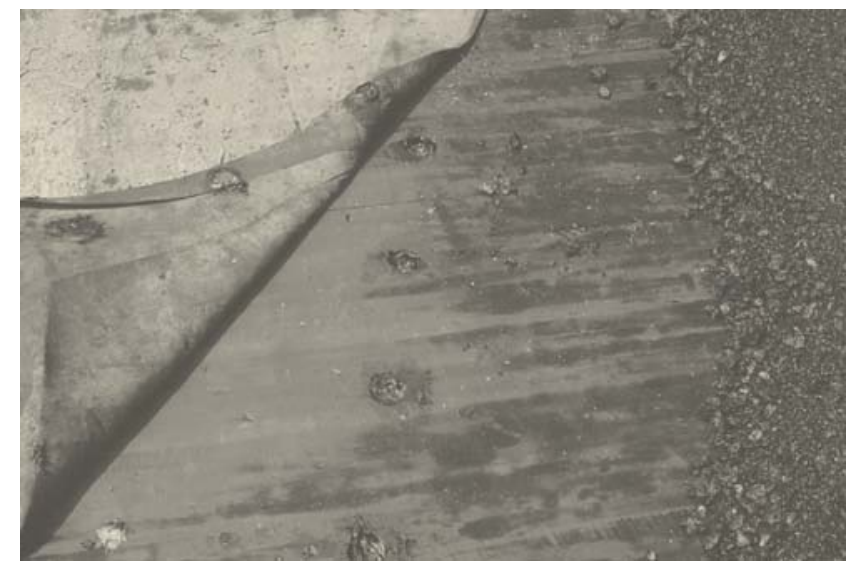

Figure 14-Oil-type preservative bleeding during paving. 


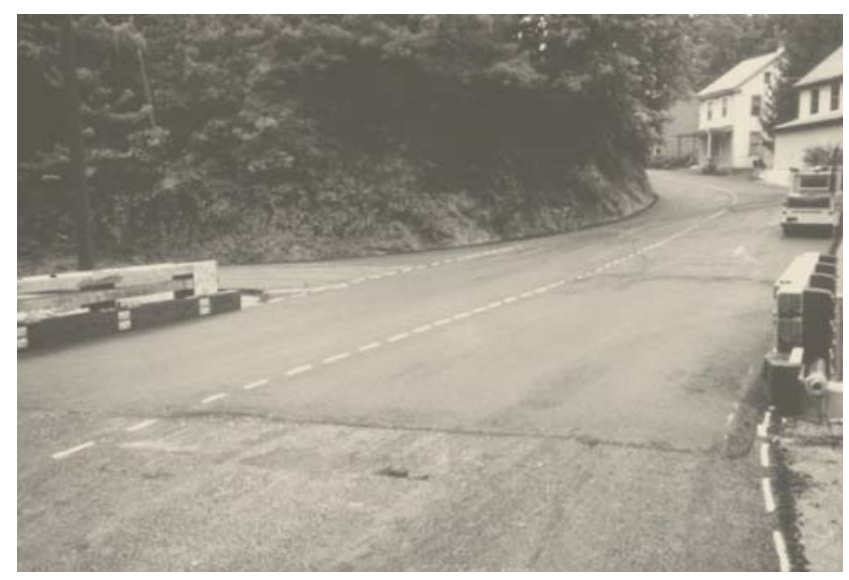

Figure 15-Clean and dry asphalt base course for membrane installation.

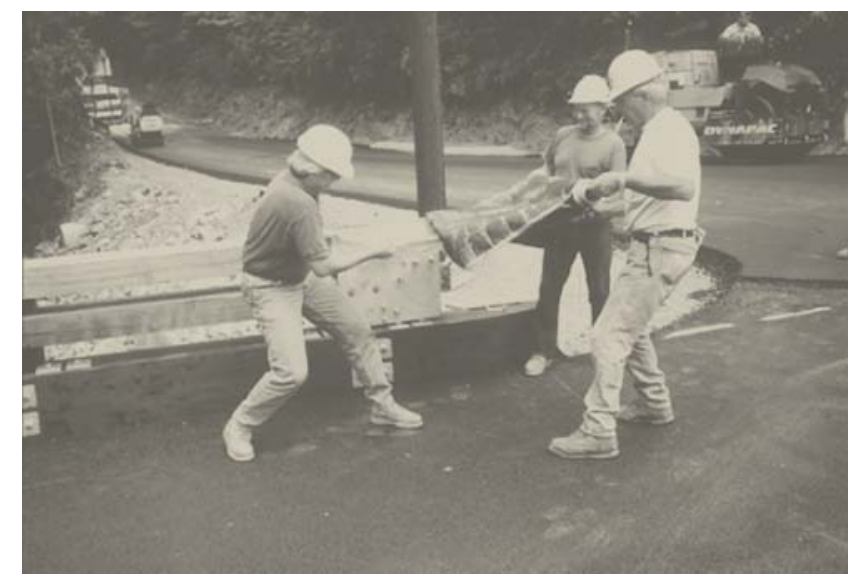

Figure 16-Membrane backing being removed.

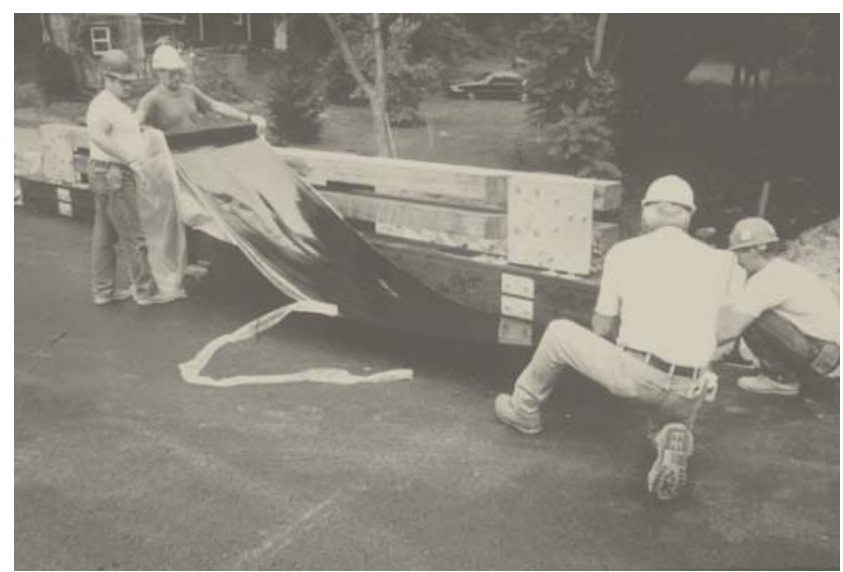

Figure 17-Membrane sheet being unrolled.

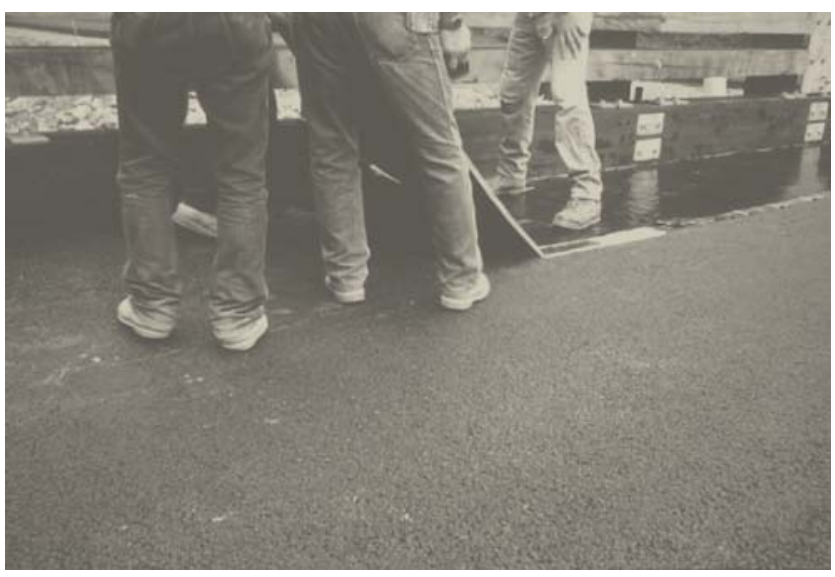

Figure 18-Sheet being unrolled over entire bridge length prior to adhering with roller.

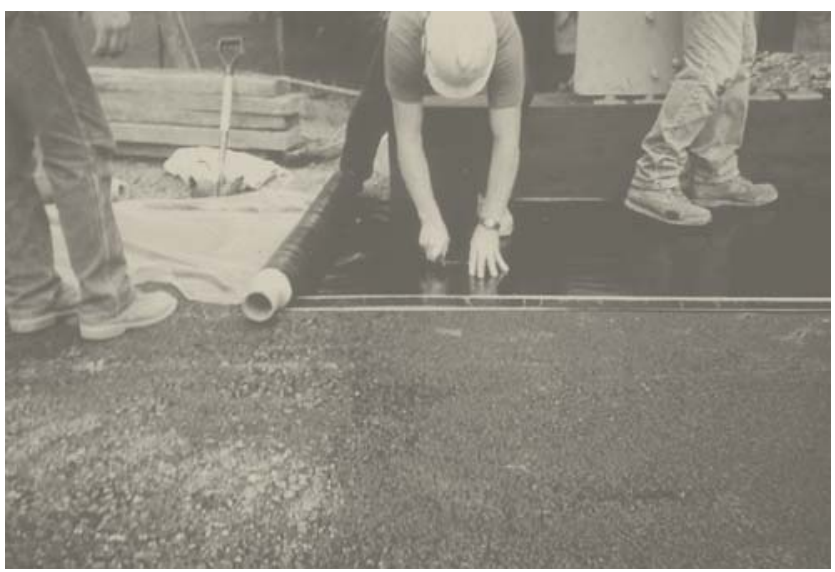

Figure 19-Sheets being cut with utility knife.

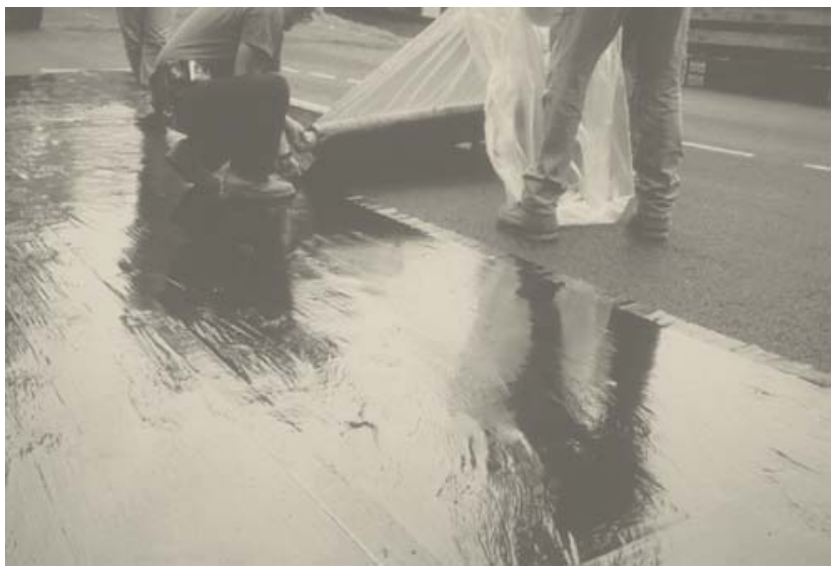

Figure 20-Membrane being installed in shingle fashion, curb to centerline. 


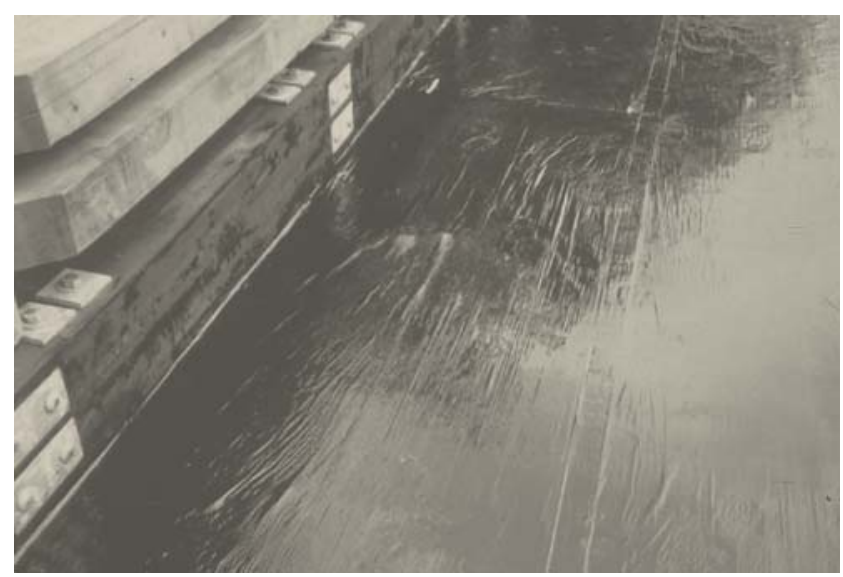

Figure 21-Edge seams are overlapped $76 \mathrm{~mm}$ (3 in.), and end seams, $152 \mathrm{~mm}$ (6 in.).

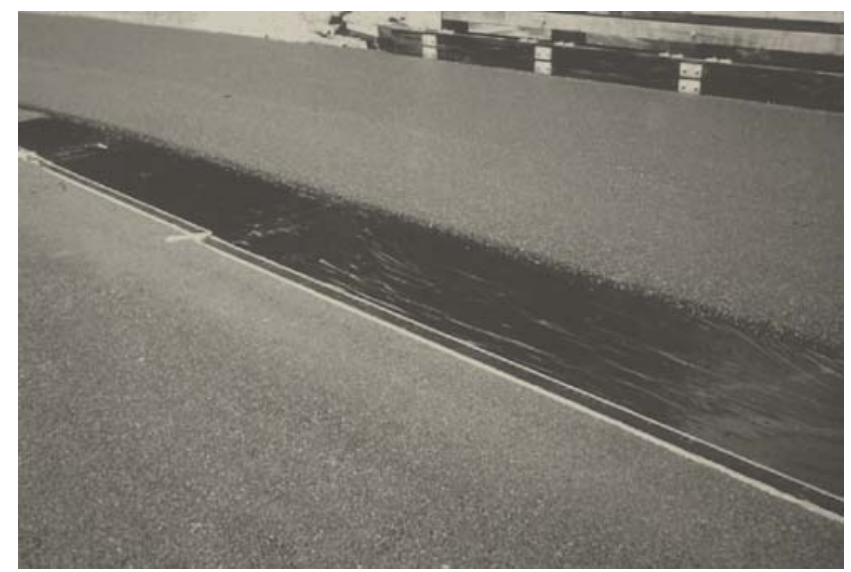

Figure 22-Debris being cleaned from membrane prior to laying surface course.

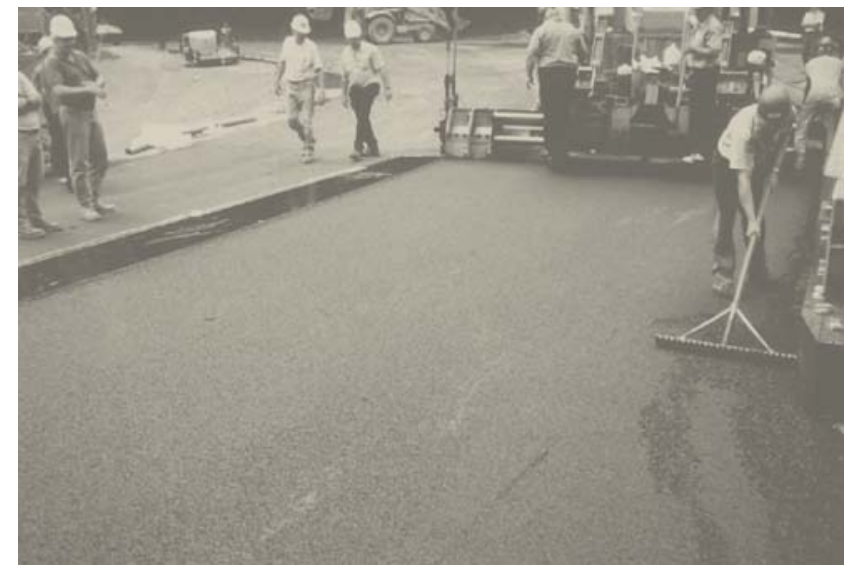

Figure 23-Asphalt being laid and compacted in accordance with agency regulations. 


\section{Appendix-Two Surface Course Mixtures}

This Appendix provides details on two surface course mixtures (SM) and two base course mixtures (BM) that have performed satisfactorily in laboratory tests and in a field application. This information is from selected sections of the Virginia Department of Transportation, "Road and Bridge Specifications", Section 211 B Asphalt Concrete.

Type SM-2A asphalt concrete shall consist of crushed stone, crushed slag, or crushed gravel and fine aggregate, slag, or stone screenings, or a combination thereof combined with asphalt cement. Not more than 5\% of the aggregate retained on the No. 4 sieve and not more than $20 \%$ of the total aggregate may be polish susceptible.

Type BM-2 asphalt concrete shall consist of coarse aggregate (crushed stone, crushed slag, or crushed gravel) and fine aggregate (slag, stone screenings, gravel screenings, or a combination thereof) combined with at least $4.4 \%$ asphalt cement.

Aggregate retention specification for asphalt concrete mixtures

\begin{tabular}{|c|c|c|c|c|c|c|c|c|c|c|c|}
\hline \multirow[b]{2}{*}{ Type } & \multicolumn{11}{|c|}{ Percentage by weight passing square mesh sieves } \\
\hline & $2 \mathrm{in.}$ & $1-1 / 2 \mathrm{in.}$ & $1 \mathrm{in.}$ & $3 / 4 \mathrm{in}$. & $2 \mathrm{in.}$ & $3 / 8$ in. & No. 4 & No. 8 & No. 30 & No. 50 & No. 200 \\
\hline SM-2A & & & & 100 & $97-100$ & 82-94 & $48-62$ & & $18-24$ & & $4-7$ \\
\hline BM-2 & & 100 & $\begin{array}{l}97- \\
100\end{array}$ & $75-90$ & & $54-74$ & & $30-38$ & & & $3-6$ \\
\hline
\end{tabular}

Design criteria for asphalt concrete mixtures ${ }^{a}$

\begin{tabular}{lccccccc}
\hline Mixture type & VTM $^{\mathrm{b}}$ & VFA $^{\mathrm{c}}$ & $\begin{array}{c}\text { Minimum } \\
\text { VFA }\end{array}$ & $\begin{array}{c}\text { Minimum } \\
\text { stability (lb) }\end{array}$ & $\begin{array}{c}\text { Flow } \\
(0.01 \text { in. })\end{array}$ & $\begin{array}{c}\text { Viscosity } \\
\text { grade }\end{array}$ & $\begin{array}{c}\text { Marshall mixed } \\
\text { design proce- } \\
\text { dure }\end{array}$ \\
\hline SM-2A & $3-6$ & $65-80$ & 15 & 1,200 & $8-16$ & AC-20 & 50 \\
BM-2 & & & & & & AC-20 & \\
\hline
\end{tabular}

${ }^{a}$ The maximum fines/aggregate (F/A) shall be 1.2:1 for surface mixtures; the maximum F/A shall be 1.4:1 for base mixtures; the minimum F/A shall be 0.6:1 for surface mixtures; the asphalt content shall be selected at the midpoint of the VTM range.

${ }^{\mathrm{b}}$ VTM, Virginia test method.

${ }^{\mathrm{c}}$ VFA, void filled with asphalt. 